\title{
The Plankton of the Sea, by R. S. Wimpenny. Faber, 84 s.
}

This book is written with such simple affection for the drifting flora and fauna of the sea that it can be read straight through by a naturalist or general reader. The author deliberately avoids jargon and also a more subtle danger, the overloading of the text from his considerable reserve of learning. And what a fascinating world it is! Omitting insects the sea carries more species than the land, often of great beauty, whose behaviour and physiology, on which the author lays special emphasis, includes much that is completely out of the land naturalist's ken.

This is the ideal first book for a student-not only because Wimpenny has cared for him with enough aid to identify most specimens, but because of its completeness, including as it does even little-known and difficult branches of the subject, such as the relation of sea conditions to production of plants and animals, and that of physiological changes in their bodies to changes in the sea. Its simplicity is deceptive: it is a very learned book by a modest and balanced scholar.

The oceans are so vast, and the sea-water so fertile, that even the increased contamination of present decades cannot appreciably harm the plankton. The medusae will pulsate, the arrow-worms dart, the water-fleas jump, and the Portuguese man-o'-war sail unconcernedly through oil where the wind and waves have broken the film into droplets, from areas of contamination by pesticides into oceans larger than continents, fed by the sun and the air, the rain and great rivers, and the much greater upwelling from rich reserves of deep water. If man, incontinent, betakes himself to his long home, the plankton will survive.

MICHAEL GRAHAM.

\section{A Draught of Fishes, by F. D. Ommanney, Longmans, $36 \mathrm{~s}$.}

Dr. Ommanney has had a long and interesting career in marine science. Using his experiences as a fishery adviser in many parts of the worldSeychelles, Zanzibar and Hong Kong-he has written some of the best modern travel books. In these fish were but one item in the background; the present volume deals wholly with fish and fishing, and particularly with science and fisheries. In it he develops the story of modern fisheries, from the basic production of phytoplankton, through the zooplankton and benthos to the fishes themselves, interspersing the strictly scientific account with illustrations and anecdotes from his own varied experiences.

The general reader will find this an interesting book and a pleasure to read, and as an introduction to fish and fisheries it can be recommended. It also has what is essential for any popular account of scientific work-a good list of references to scientific literature in which the interested reader can find the more detailed scientific reports. Unfortunately it is regrettably full of mistakes and slips, some of them rather startling, though ultimately not serious. For instance Swedish fishermen would be very gratified if their catches (p. 213) included 200,000 to 300,000 tons of salmon from the sea (actually the figure is not much more than 300), though these salmon may be like the Icelandic cod which are reported (p. 38) to weigh "up to $100 \mathrm{lb}$., but usually not more than 50 or $60 \mathrm{lb}$."; (the average size in English catches is about $5 \mathrm{lb}$.). Other errors are more important; dealing with the problems of conservation and management, he can be badly misleading. An increasing proportion of small fish, or a decline in the stock, or in the catch per boat are signs that fishing is having an effect on a stock of fish, not that this effect has become too great. Irritating as these errors may be to the scientist or the fisherman, they should not spoil the pleasure of the general reader. Once his interest is aroused, as it should be, he has only himself to blame if he fails to follow it up in the scientific literature to which the book is a welcome signpost.

J. A. CULLAND. 